\title{
MOLECULAR TYPING OF RICKETTSIA AKARI
}

\author{
M.E. Eremeeva ${ }^{a}$, M.M. Sturgeon , J.K. Willard ${ }^{b}$, S.E. Karpathy ${ }^{b}$, A. Madan ${ }^{c}$, \\ G.A. Dasch \\ ${ }^{a}$ Jiann-Ping Hsu College of Public Health, Georgia Southern University, Statesboro, GA, USA \\ ${ }^{b}$ Rickettsial Zoonoses Branch, Division of Vector-Borne Diseases, National Center for Emerging and Zoonotic Infectious Diseases, \\ Centers for Disease Control and Prevention (CDC), Atlanta, Georgia, USA \\ ${ }^{c}$ Covance Genomics Laboratory, Redmond, WA, USA
}

\begin{abstract}
Rickettsia akari, an obligately intracellular bacterium, is the causative agent of the cosmopolitan urban disease rickettsialpox. R. akari is an atypical representative of spotted fever group rickettsiae (SFG) as it is associated with rodent mites rather than ticks or fleas; however, only limited information is available about the degree of genetic variability found among isolates of $R$. akari. We examined 13 isolates of $R$. akari from humans, rodents and mites in the USA, the former Soviet Union, and the former Yugoslavia made between 1946 and 2003 for diversity in their tandem repeat regions (TR) and intergenic regions (IGR). The 1.23 Mb genome of $R$. akari strain Hartford CWPP was analyzed using Tandem Repeat Finder software (http://tandem.bu.edu) and 374 different TRs were identified, with size variation from 1 to 483 bp and with TR copy numbers ranging between 21 and 1.9, respectively. No size polymorphisms were detected among the 11 TR regions examined from 5 open reading frames and 6 IGR. Eighteen non-TR IGR's were amplified and sequenced for the same isolates comprising a total of $5.995 \mathrm{bp}(0.49 \%)$ of the Hartford CWPP strain chromosome. Three single nucleotide polymorphism (SNP) sites were detected in two IGR's which permitted separation of the five $R$. akari isolates from Ukraine SSR from the other eight isolates. In conclusion, this is the first study reporting genetic heterogeneity among $R$. akari isolates of different geographic origins. Further exploration of this genetic diversity is needed to understand better the geographic distribution of $R$. akari and the epidemiology of rickettsialpox. The potential of mites as hosts for other rickettsial agents also needs further investigation.
\end{abstract}

Key words: rickettsialpox, mite, Liponyssoides sanguineus, Rickettsia akari, rickettsiae, spotted fever group rickettsiae, tandem repeats, intergenic regions, genotyping, multilocus sequence typing.

\section{ГЕНЕТИЧЕСКОЕ ТИПИРОВАНИЕ RICKETTSIA AKARI}

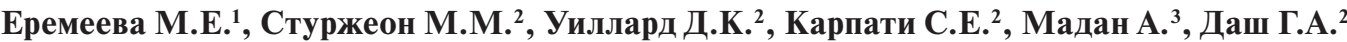

${ }^{1}$ Колледж народного здравоохранения им. Цзянн-Пин Хсу, Университет Южной Джорджии, Стейтсборо, Джорджия, США

${ }^{2}$ Центр Контроля и Профилактики Заболеваний, Атланта, Джорджия, США

${ }^{3}$ Кованс Геномик лаборатория, Редмонд, Вашингтон, США

Резюме. Rickettsia akari является облигатной внутриклеточной бактерией и вызывает осповидный риккетсиоз. Rickettsia akari является атипичным представителем группы риккетсиозных пятнистых лихорадок (SFG), поскольку она циркулирует в гамазовых клешах; однако в отношении степени генетического разнообразия изолятов $R$. akari имеются лишь ограниченные данные. Мы изучили 13 изолятов $R$. akari, выделенных от человека, грызунов и клещей в США, странах бывшего СССР и бывшей Югославии за период с 1946 по 2003 г. на предмет разнообразия в составе тандемных повторов (TR) и межгенных районов (IGR).

\section{Адрес для переписки: \\ Еремеева Марина Евгеньевна \\ 30458, США, Джорджия, Стейтсборо, почтовый ящик 8015, \\ Университет Южной Джорджии. \\ Тел.: +1 912 478-05-04. Факс: +1 912 478-58-11. \\ E-mail: meremeeva@georgiasouthern.edu}

\section{Библиографическое описание:}

Еремеева М.Е., Стуржеон М.М., Уиллард Д.К., Карпати С.Е., Мадан А., Даш Г.А. Генетическое типирование Rickettsia akari // Инфекция и иммунитет. 2020. Т. 10, № 3. C. 497-505. doi: 10.15789/2220-7619MTO-1295

(c) Eremeeva M.E. et al., 2020

\author{
Contacts: \\ Marina E. Eremeeva \\ Georgia Southern University PO Box 8015, Statesboro, GA 30458, USA. \\ Phone: +1 912 478-05-04. Fax: +1 912 478-58-11. \\ E-mail: meremeeva@georgiasouthern.edu
}

\section{Citation:}

Eremeeva M.E., Sturgeon M.M., Willard J.K., Karpathy S.E., Madan A., Dasch G.A. Molecular typing of Rickettsia akari // Russian Journal of Infection and Immunity = Infektsiya i immunitet, 2020, vol. 10, no. 3, pp. 497-505. doi: 10.15789/2220-7619-MTO-1295

DOI: http://dx.doi.org/10.15789/2220-7619-MTO-1295 
При помощи программы Tandem Repeat Finder software (http://tandem.bu.edu) по поиску тандемных повторов Tandem Repeat Finder (http://tandem.bu.edu) был проанализирован геном длиною 1,23 Мб штамма $R$. akari Hartford CWPP; обнаружены 374 различных TR размером от 1 до 483 п.н. и количестве копий TR колеблющихся от 21 до 1,9 соответственно. Среди 11 TR из 5 открытых рамок считывания и 6 IGR не обнаружено размерного полиморфизма. Восемнадцать не-TR IGR были амплифицированы и секвенированы из всех изолятов, составляющих в целом 5995 п.н. (0,49\%) хромосомы штамма Hartford CWPP. Три точечные мутации (SNP) были обнаружены в двух IGR, что позволило отделить пять изолятов R. akari из Украинской CCP от восьми других изолятов. В заключение следует отметить, что настоящее исследование является первым описанием генетического разнообразия среди изолятов $R$. akari из различных географических регионов. Дальнейшее изучение генетического разнообразия необходимо для более точного понимания географического распространения R. akari и эпидемиологии осповидного риккетсиоза. Оценка потенциала гамазовых клещей в качестве хозяев для возбудителей других риккетсиозов также требует дополнительных исследований.

Ключевые слова: осповидный риккетсиоз, гамазовые клещи, Liponyssoides sanguineus, Rickettsia akari, pиккетсии, генотипирование, тандемные повторы, межгенные фрагменты, мультилокусное генотипирование.

\section{Introduction}

Rickettsia akari is an obligate intracellular gramnegative bacterium which causes rickettsialpox in humans $[2,21]$. The etiological agent is thought to have a worldwide distribution [31]. R. akari circulates in natural reservoirs of rats and house mice, Mus musculus, and is transmitted to humans by the bite of the mouse mite, Liponyssoides sanguineus [2, 22]. The transmission typically occurs in situations associated with disturbances of peridomestic structures infested by the rodents, rodent-infested and crowded conditions, or when the rodent population is reduced substantially or eliminated by rodent control or illnesses [1, 26, 31, 44]. Rickettsialpox is one of the few rickettsioses which is characterized as an urban disease. Clinically, it manifests as a mild disease accompanied by the classic triad of the eschar lesion at a site of the mite bite, fever, and vesicular rash, as well as headache and lymphadenopathy and leukopenia [2, $3,21,31]$.

At the time of its discovery, large scale outbreaks of rickettsialpox were identified in the United States and Ukraine SSR of the former Soviet Union (hereafter Ukraine) [2, 3, 21], and for the subsequent decade rickettsialpox received substantial attention from the public health and medical communities [31]. Serological surveys determined the prevalence of $R$. akari infections in several European, Central American and African countries [31]; however, disease reporting quickly diminished after that and only sporadic reports appeared in the peer-reviewed literature [31, 35]. Rickettsialpox received renewed attention at the beginning of the $21^{\text {st }}$ century due to the need for differential diagnostic assessment for cutaneous lesions since its vesicular rash and later scab could lead to misidentification as chickenpox, herpes, and/or anthrax [5, 25, 31, 33, 46]. More recently clinically and laboratory confirmed cases of rickettsialpox have been reported from the USA, Ukraine, the former Yugoslavia (Croatia), Turkey, Netherlands and Mexico [29, 31, 35, 38, 46].
Rickettsia akari strains which were isolated from patients, mice, rats and mites from areas in the USA and Ukraine exhibit identical features when compared with classical identification methods, by using restriction fragment polymorphism analysis of the glt $A$ and $о т p B$ amplicons, and with whole genome restriction profiles using pulsed-field gel electrophoresis [11, 12]. A Croatian isolate from the former Yugoslavia also could not be distinguished from reference USA $R$. akari strains using serological methods and monoclonal antibody typing [35], and similar conclusions were derived for $R$. akari responsible for rickettsialpox in Turkey [29] and Mexico but the latter samples were not typed [46]. These observations suggest that a single ancestral strain of $R$. akari was widely disseminated around the globe with rodents and their mites. The purpose of this study was to perform deeper genetic analysis of the available $R$. akari isolates from various geographic locations; we compared their variability in some of the tandem repeat sites and intergenic regions that could be identified from the complete genome sequence of $R$. akari Hartford CWPP strain (NCBI accession \# NC_009881).

\section{Materials and Methods}

R. akari isolates and DNA extraction. Fourteen stocks of strains of $R$. akari that were isolated from humans, rodents and mites in the USA, the former Soviet Union, and former Yugoslavia between 1946 and 2003 were analyzed. The five Ukrainian strains were from the Reference Collection of the Gamaleya Research Institute of Epidemiology in Moscow. The isolates from the U.S. consisted of the Kaplan (MK) reference strain isolated in 1946 from a patient in New York City, five isolates from patients in various locations in New York during 2001 to 2003 [32], and two stocks of Hartford strain: CWPP (plaque-purified by Charles Wisseman, Jr., from the University of Maryland School of Medicine) and an earlier unpurified passage Hartford H5564 (from the Harvard 
University School of Public Health Collection) which was isolated from house mouse mites collected in West Hartford, Connecticut in 1952 (J. Spielman personal communication and [15]). The $R$. akari Croatian strain was isolated from a human from Yugoslavia in 1991 [35], and was obtained from David H. Walker (University of Texas Medical Branch, Galveston, TX). All strains were propagated in embryonated chicken eggs and passaged in Vero E6 cells and their whole cell DNAs (Vero cell DNA and Rickettsia DNA) were extracted using QIAamp protocol according to the manufacturer's instructions (Qiagen, Valencia, CA). Extracted DNAs were stored at $+4^{\circ} \mathrm{C}$ before analysis.

Tandem repeat site identification and analysis. The $1.23 \mathrm{Mb}$ genome of $R$. akari strain Hartford CWPP (NCBI accession \# NC_009881) obtained from DNA from Vero cell propagated and Renografin purified rickettsiae at the CDC was analyzed for the presence and distribution of tandem repeats using Tandem Repeat (TR) Finder software version 3.21 with advanced parameters setting (http://tandem. bu.edu) [4]. The predicted tandem repeat sites were catalogued according to their size and their individual characteristics (fig. 1). Primers were designed for selected TR sites containing identical repeats with a period size of 6 to 17 nucleotides (tabl. 1) whose variable periodicity would be distinguishable by agarose gel electrophoresis. All amplifications were conducted using Taq polymerase (Qiagen, Valencia, CA) and $20 \mathrm{pmol}$ of each forward and reverse primer, and cycling conditions consisted of 40 cycles of $1 \mathrm{~min}$ at $95^{\circ} \mathrm{C}, 30 \mathrm{sec}$ at $50^{\circ} \mathrm{C}$, and $1 \mathrm{~min}$ at $68^{\circ} \mathrm{C}$. Resulting amplicons were analyzed by electrophoresis in $1 \%$ agarose gels in $0.5 \mathrm{X}$ Tris-Borate-EDTA buffer $(\mathrm{pH}$ 8.0 ) for $30 \mathrm{~min}$ at $80 \mathrm{~V}$ and stained with ethidium bromide.

Analysis of intergenic regions. To identify intergenic region (IGR) spacers that might exhibit variable sequences in different isolates, homologous sequences of pairs of adjacent genes and their IGR were aligned for $R$. akari Hartford CWPP and $R$. rickettsii Sheila Smith (NCBI accession number NC_009882). Of these, 18 of 28 sites evaluated were selected for further analysis based on the level of intraspecies variations found in $R$. rickettsii, $R$. prowazekii and $R$. conorii $[17,23,49]$. The primers used to amplify each IGR and predicted sizes for each amplicon are listed in table 2. All amplifications were conducted using Taq polymerase (Qiagen) according to the PCR protocol described previously [23]. Resulting amplicons from different isolates were analyzed for size variability by electrophoresis in the same $1 \%$ agarose gels run for $30 \mathrm{~min}$ at $80 \mathrm{~V}$ as described above.
A

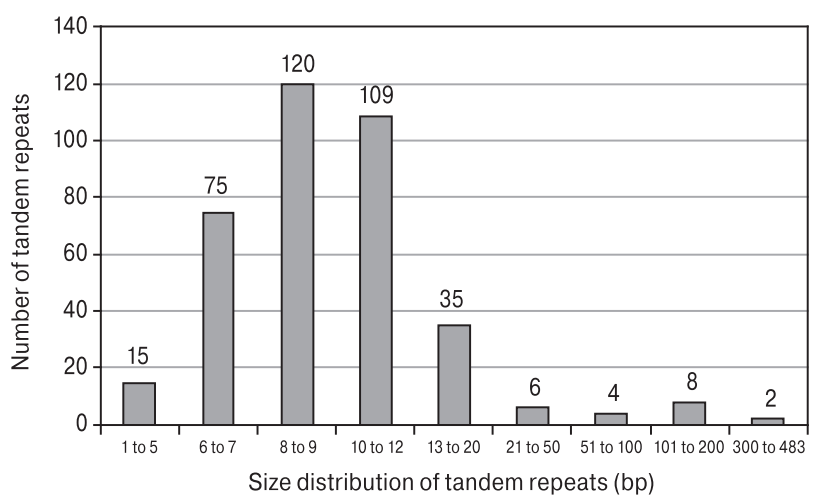

C

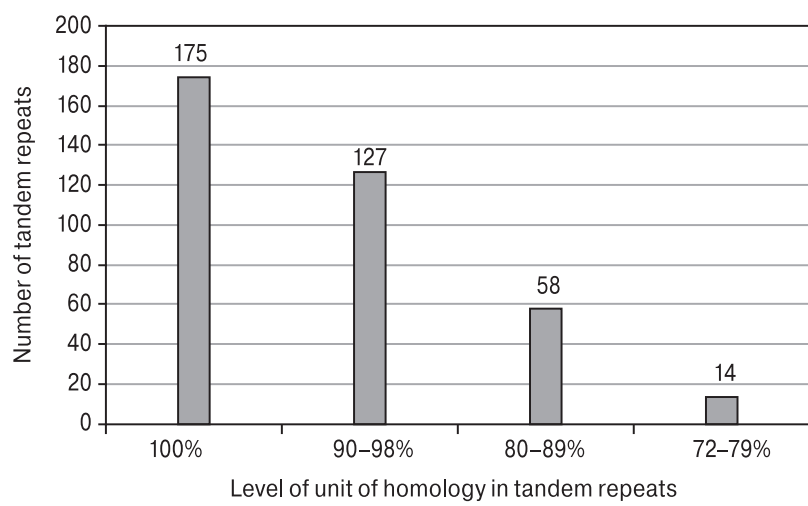

B

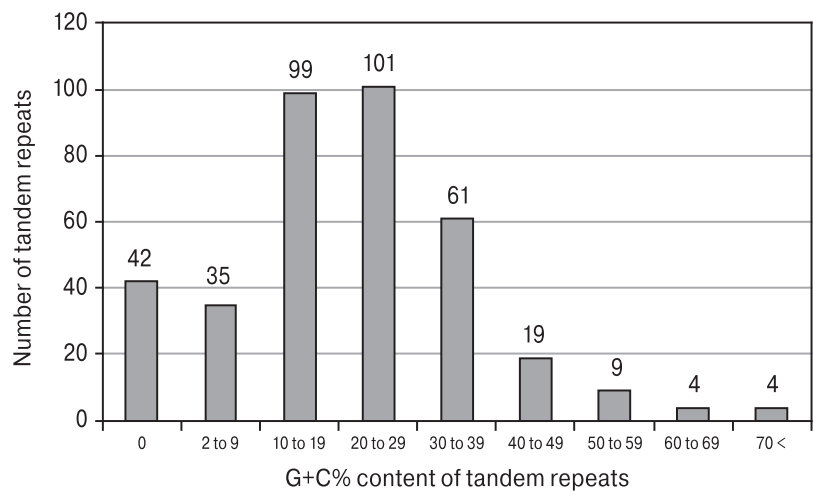

D

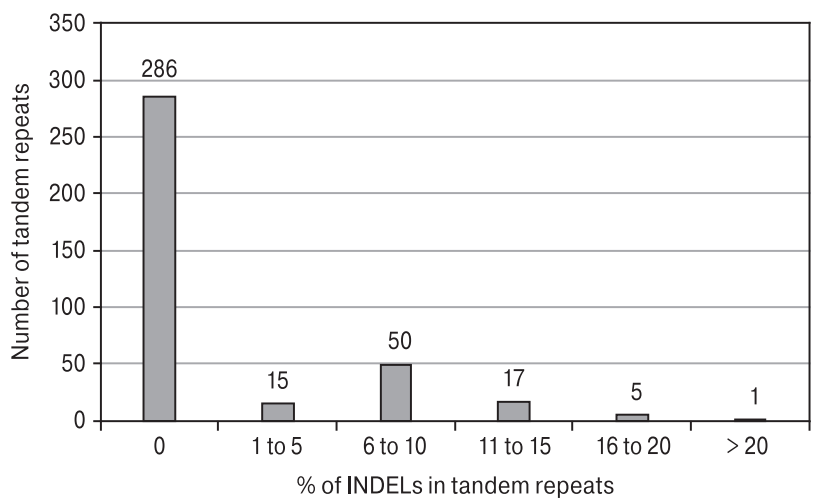

Figure 1. Properties of tandem repeat regions identified in $\boldsymbol{R}$. akari Hartford CWPP

A) Size distribution of tandem repeats; B) G+C\% content of tandem repeats; C) Level of unit homology in tandem repeats;

D) \% of INDEL in tandem repeats 
Sequencing and sequence analysis. Amplicons were purified using the Wizard SV gel and PCR cleanup system (Promega, Madison, WI). Purified PCR fragments were sequenced in both directions using a BigDye Terminator v3.1 cycle sequencing kit (Applied Biosystems, Foster City, CA) according to the manufacturer's directions, using an ABI 3100 genetic analyzer (Applied Biosystems). Sequencing reads were assembled using the SeqMerge program of the GCG software package (Accelrys, San Diego, CA). Identity of each sequence was confirmed using BLAST and sequence comparisons were done using the ClustalW alignment program as formulated in MEGA3 [27]. New sequences generated as a part of this study were submitted to the NCBI GenBank under the following accession numbers: MN524593MN524601.

\section{Results}

Analysis of the $R$. akari Hartford CWPP tandem repeat regions. The characteristics of the tandem repeats (TR) present in the $R$. akari Hartford CWPP genome are summarized in Figure 1. The TR analysis identified 374 different loci containing tandem repeats, with repeat size variation from 1 to $483 \mathrm{bp}$ and with copy numbers ranging between 1.9 and 21 . Eleven selected primer pairs produced a single band of the predicted size when using DNA of Hartford CWPP strain (tabl. 1). Homologous amplicon frag- ments were obtained for each $R$. akari isolate DNA available; the yield of PCR amplicons for each TR region was comparable for each set of primers thus permitting direct comparisons of their sizes. No electrophoretic polymorphisms were detected among the 11 $\mathrm{TR}$ regions examined with a repeat motif of $6 \mathrm{bp}$ to $17 \mathrm{bp}$; these regions were amplified from 5 open reading frames and 6 intergenic regions.

Analysis of the intergenic regions. Of the twentyone sets of IGR primers tested, 18 sets clearly amplified fragments of IGRs as expected with Hartford CWPP DNA; these were located in all regions of the chromosome of R. akari Hartford CWPP (tabl. 2). There was no overlap between TR identified in IGR of the $R$. akari genome (tabl. 1) and the IGR sites tested in this portion of the study. The eighteen pairs all amplified a single fragment of the same size from the genomic DNAs for each of the 14 isolate DNA tested. Lack of detectable differences in electrophoretic mobility suggested that INDELs $>6$ bp were not present among the homologous fragments analyzed. Indeed, when sequenced, 16 of 18 amplicons had identical nucleotide sequences for all 14 DNAs to the genome sequence of Hartford CWPP isolate. Only two IGRs contained single nucleotide polymorphisms (SNP): one SNP was found within the lig-tgt IGR amplicon, and two SNPs were identified within the $t \mathrm{RNA}^{\mathrm{Leu}}-m g t \mathrm{E}$ IGR amplicon (tabl. 2). Thus, the tested IGR genome regions are highly conserved among the available isolates of $R$. akari.

Table 1. Tandem repeat sites and primers used to analysis these regions

\begin{tabular}{|c|c|c|c|c|}
\hline Target site and its location & Primer $\left(5^{\prime}-3^{\prime}\right)$ & $\begin{array}{c}\text { Amplicon size } \\
\text { (bp) based on } \\
\text { the reference } \\
\text { genome }\end{array}$ & $\begin{array}{l}\text { Repeat motif in the } \\
\text { reference genome }\end{array}$ & $\begin{array}{c}\text { Size (number) } \\
\text { of repeats in } \\
\text { the reference } \\
\text { genome }\end{array}$ \\
\hline AKTR $27720-27727(C)^{\star}$ & $\begin{array}{l}\text { F: AAATCGTACGGCTAGTACAA } \\
\text { R: CTAAATCTCTTTCCGATGCTT }\end{array}$ & 225 & TTAAAAAAT & 9 bp (2) \\
\hline AKTR 63635-63650 (C) & $\begin{array}{l}\text { F: TCTGAATCACTCACCGGTTC } \\
\text { R: ACGGGTTTTTCAGGACTTAAT }\end{array}$ & 242 & GATTTGAT & $8 \mathrm{bp}(2)$ \\
\hline AKTR 109301-109324 (C) & $\begin{array}{l}\text { F: AGCTAATTCCGCATCTT } \\
\text { R: AGTTTATTGCGATAGTCAAGG }\end{array}$ & 296 & GGTGGC & $6 \mathrm{bp}(4)$ \\
\hline AKTR 117808-117823 (IGR) & $\begin{array}{l}\text { F: GCCCTCTCCACTATCAGAT } \\
\text { R: TTACGAAGTTTCTGCCATAGC }\end{array}$ & 227 & ATTTTTGT & $8 \mathrm{bp}(2)$ \\
\hline AKTR 150931-150964 (IGR) & $\begin{array}{l}\text { F: GCTATGGCTCCGGGTAGAAT } \\
\text { R: TTACGCTGTGAATCCGGTGAA }\end{array}$ & 846 & ATCGTCATTGCAAGCAG & 17 bp (2) \\
\hline AKTR 204937-204954 (IGR) & $\begin{array}{l}\text { F: GAAGTCCTGTGGTTCCGATT } \\
\text { R: TATAGGTCTTAGCGGTTCTAC }\end{array}$ & 239 & TAAATCATC & 9 bp (2) \\
\hline AKTR 239619-239634 (IGR) & $\begin{array}{l}\text { F: CCCAGGGCAGAAGTATCATT } \\
\text { R: AATAAGTATTGCGTATGGCTT }\end{array}$ & 278 & CATAATTT & $8 \mathrm{bp}(2)$ \\
\hline AKTR 261657-261672 (C) & $\begin{array}{l}\text { F: AAATAGTTGGGAAGTTAATGA } \\
\text { R: AATATGGCAATGCTTACC }\end{array}$ & 328 & GCTATATT & $8 \mathrm{bp}(2)$ \\
\hline AKTR 288108-288135 (IGR) & $\begin{array}{l}\text { F: TTAGGTGGTACGGCAGA } \\
\text { R: CTTATCGCAGCGTATTACGTC }\end{array}$ & 421 & TCATAAGAAATAAA & 14 bp (2) \\
\hline AKTR 347653-347670 (C) & $\begin{array}{l}\text { F: AAGCGGCTGATGATATTG } \\
\text { R: TTTAGTGCCGTTTCTTCGATA }\end{array}$ & 775 & CAATATAAA & $9 \mathrm{bp}(2)$ \\
\hline AKTR 417521-417540 (IGR) & $\begin{array}{l}\text { F: ACAACGCCGATTATATCAA } \\
\text { R: GCAACTGCCGAACTATCAACC }\end{array}$ & 185 & AATAATAGCA & 10 bp (2) \\
\hline
\end{tabular}

${ }^{\star} \mathrm{C}$, coding sequence, IGR, intergenic regions 
The IGR lig-tgt SNP at nucleotide 369 is shared among all the USA isolates and the isolate from Croatia but is different from the homologous nucleotide in all five of the isolates from the Ukraine (tabl. 2). The USA and Croatian isolates have a $\mathrm{C} \mid \mathrm{T}$ substitution as compared with the Ukrainian isolates. The annotation of the R. akari Hartford CWPP genome contains two small open reading frames on the reverse strand of the 458-bp lig-tgt intergenic region, one of $195 \mathrm{nt}$ encoding a 65-aa hypothetical protein and another of 228-nt encoding a 75-aa protein which belongs to a family of toxin-antitoxin proteins. The $\mathrm{C} \mid \mathrm{T}$ substitution results in a corresponding methionine-to-valine change in the amino acid sequence of the latter protein. The $t \mathrm{RNA}^{\mathrm{Leu}}-m g t \mathrm{E}$ IGR, contained two SNPs at nucleotides 173 and 215 of the amplicon. These SNPs could also be linked with the same two groups of geographic locations found in the lig-tgt region: the Croatian and all the USA isolates have a $\mathrm{G} \mid \mathrm{A}$ substitution at nucleotide 173 and an $\mathrm{A} \mid \mathrm{T}$ substitution at nucleotide 215 when compared to the Ukrainian isolates.

\section{Discussion}

The most recent classifications based on conserved genetic attributes places $R$. akari into a socalled transitional group that also includes flea-borne Rickettsia felis and related organisms, Rickettsia australis, and Rickettsia hoogstraalii [19]. Genetic analysis of $R$. akari isolates of various geographic origins conducted in this study revealed a substantial level of genome conservation in the $0.5 \%$ of the genome we sampled by sequencing IGR regions that vary significantly from homologous regions in other SFGR. This suggests that a single ancestral strain

Table 2. Primers used to analyze intergenic regions*

\begin{tabular}{|c|c|c|c|}
\hline Target region & Primers $\left(5^{\prime}-3^{\prime}\right)$ & $\begin{array}{c}\text { Size } \\
\text { (R. akari) }\end{array}$ & $\begin{array}{c}\text { Size } \\
\text { (R. rickettsii) }\end{array}$ \\
\hline SpoOJ-abcT1 & $\begin{array}{l}\text { F: AAAGATTTGGAAGAATTAGACTTGAT } \\
\text { R: TTTGCTTAAACCAACCATTTCA }\end{array}$ & 227 bp & 272 bp \\
\hline RC1137-tlc5 & $\begin{array}{l}\text { F: CGGGATAACGCCGAGTAATA } \\
\text { R: ATGCCGCTCTGAATTTGTTT }\end{array}$ & 377 bp & 316 bp \\
\hline Pal-RC1201 & $\begin{array}{l}\text { F: TGCAAGCACACATAATGCAA } \\
\text { R: TCAAAATCGATTCCTCTTTTCC }\end{array}$ & $253 b p$ & $247 \mathrm{bp}$ \\
\hline RC1027-XthA2 & $\begin{array}{l}\text { F: GGTATGTAAATGAGCCTTATCAATACT } \\
\text { R: TCAGTAGTATAAGTAGCTCCTGCTGTC }\end{array}$ & $151 \mathrm{bp}$ & $135 \mathrm{bp}$ \\
\hline$n u s G-r p / K$ & $\begin{array}{l}\text { F: CAGTTGCAATATTGGTAAAGCA } \\
\text { R: CAGCAGCTGGAATTATCAAGTT } \\
\end{array}$ & 289 bp & 344 bp \\
\hline dskA-xerC & $\begin{array}{l}\text { F: TCCCATAGGTAATTTAGGTGTTTC } \\
\text { R: TACTACCGCATATCCAATTAAAAA }\end{array}$ & 108 bp & 177 bp \\
\hline $\operatorname{cspA}-t$ RNA ${ }^{\text {Leu }}$ & $\begin{array}{l}\text { F: CGCCATTGTCCTGTTCAATA } \\
\text { R: TCCGTTATGTCTACCATTCCA }\end{array}$ & $460 \mathrm{bp}$ & 459 bp \\
\hline PCNB3 & $\begin{array}{l}\text { F: AATTTCGGCTTTCTCACA } \\
\text { R: CTTGGCGTTTGCTTGGTCT }\end{array}$ & 255 bp & $255 \mathrm{bp}$ \\
\hline rpoB-rpoC & $\begin{array}{l}\text { F: CAGGCATTCCTGAATCATTT } \\
\text { R: TCCGTAAAAATTTACTACGCTCA }\end{array}$ & 385 bp & 324 bp \\
\hline 23S-5S rRNA & $\begin{array}{l}\text { F: ACCACCACGTTGATAGGTC } \\
\text { R: GGGATCGTGTGTTTCACTCA }\end{array}$ & $345 b p$ & $351 \mathrm{bp}$ \\
\hline yqiX-gatB & $\begin{array}{l}\text { F: CTGCGGCAGTACCGACTATT } \\
\text { R: ATCCGACGCTTGTGAATCAG }\end{array}$ & $305 \mathrm{bp}$ & 358 bp \\
\hline rne-CoxW & $\begin{array}{l}\text { F: CGGAAAAGAATGCAGAGTCTTG } \\
\text { R: CCATTTTGTAATTAAACTTTTCTGC }\end{array}$ & $121 \mathrm{bp}$ & $241 \mathrm{bp}$ \\
\hline RC0241-0242 & $\begin{array}{l}\text { F: AGCTCAAATTGTGGTGTTTCC } \\
\text { R: GGGATCCCTATTACAGCAAAA }\end{array}$ & 349 bp & 394 bp \\
\hline dnaN-RC0584 & $\begin{array}{l}\text { F: TCGTCATGCCTGTTAAGGTG } \\
\text { R: TTGGATAATCACCCGCTAAGA }\end{array}$ & $351 \mathrm{bp}$ & $417 \mathrm{bp}$ \\
\hline RC0102-0103 & $\begin{array}{l}\text { F: GCGATAAGCGATTTATTAGGC } \\
\text { R: GAAAGCCTAAAGCCTCCACA }\end{array}$ & $359 \mathrm{bp}$ & 344 bp \\
\hline lig-tgt & $\begin{array}{l}\text { F: TTTTTGTGCTTCCTCTTCAGAT } \\
\text { R: CCAAAATCTCATGAGCCGTA }\end{array}$ & $524 \mathrm{bp}$ & $395 \mathrm{bp}$ \\
\hline tmk-ProP4 & $\begin{array}{l}\text { F: TTCCCCTCCCTCAAATGTAA } \\
\text { R: CGGAGCAAGAAACCCATAAA }\end{array}$ & $361 \mathrm{bp}$ & $359 \mathrm{bp}$ \\
\hline$t \mathrm{RNA}^{\mathrm{Leu}}-m g t \mathrm{E}$ & $\begin{array}{l}\text { F: AGCATTGAGGGTGCTGTTCT } \\
\text { R: TTCAGCAAATTGATCGTGATG }\end{array}$ & 452 bp & 342 bp \\
\hline
\end{tabular}

*Primer designation and their sequences are defined according to previously published information [16]. 
Table 3. Origin of $\boldsymbol{R}$. akari isolates and position of SNPs in intergenic regions

\begin{tabular}{|c|c|c|c|c|c|c|}
\hline Isolate & $\begin{array}{c}\text { Geographic } \\
\text { origin }\end{array}$ & Year & Source & $\begin{array}{c}\text { lig-tgt } \\
\text { (nt 377 } \\
\text { of amplicon)* }\end{array}$ & $\begin{array}{c}\text { tRNALeu-mgtE } \\
\text { (nt 193 } \\
\text { of amplicon) }\end{array}$ & $\begin{array}{c}\text { tRNALeu-mgtE } \\
\text { (nt 235 } \\
\text { of amplicon) }\end{array}$ \\
\hline Hartford CWPP & USA & 1952 & Mouse mite & $\mathrm{C}$ & $\mathrm{G}$ & $\mathrm{A}$ \\
\hline Hartford H5564 & USA & 1952 & Mouse mite & $\mathrm{C}$ & $\mathrm{G}$ & $\mathrm{A}$ \\
\hline Kaplan & USA & 1946 & Human & $\mathrm{C}$ & $\mathrm{G}$ & $\mathrm{A}$ \\
\hline Columbia1 & USA & 2001 & Human & $\mathrm{C}$ & $\mathrm{G}$ & $\mathrm{A}$ \\
\hline Columbia2 & USA & 2002 & Human & $\mathrm{C}$ & $\mathrm{G}$ & $\mathrm{A}$ \\
\hline Columbia3 & USA & 2002 & Human & $\mathrm{C}$ & $\mathrm{G}$ & $\mathrm{A}$ \\
\hline Bronx & USA & 2002 & Human & $\mathrm{C}$ & $\mathrm{G}$ & $\mathrm{A}$ \\
\hline Manhattan & USA & 2003 & Human & $\mathrm{C}$ & $\mathrm{G}$ & $\mathrm{A}$ \\
\hline Croatian & Yugoslavia & 1991 & Human & $\mathrm{C}$ & $\mathrm{G}$ & $\mathrm{A}$ \\
\hline As4 & Ukraine & 1950 & Mite & $\mathrm{T}$ & $\mathrm{A}$ & \\
\hline Aschkalunin & Ukraine & 1950 & Human & $\mathrm{T}$ & $\mathrm{A}$ & $\mathrm{T}$ \\
\hline M3 & Ukraine & 1950 & Mouse & $\mathrm{T}$ & $\mathrm{A}$ & $\mathrm{T}$ \\
\hline R1 & Ukraine & 1950 & Rat & $\mathrm{T}$ & $\mathrm{ND}$ & $\mathrm{T}$ \\
\hline Toger & Ukraine & 1950 & Human & $\mathrm{T}$ & $\mathrm{A}$ & $\mathrm{N}$ \\
\hline
\end{tabular}

${ }^{*}$ Nucleotide position of the sequenced portion of the amplicon is indicated.

of $R$. akari has spread globally with their rodent and rodent mite hosts. We found three stable SNPs that permitted identification of two geographic variant types of $R$. akari. These findings underscore the need for further research and evaluation of this neglected species of pathogenic Rickettsia. Known examples with diversity of $R$. bellii organisms and an expanding list of near relatives of $R$. felis $[6,18,25,28,48]$ suggest our sampling of relatives of $R$. akari and possibly other variants of $R$. akari may be far from complete.

In clinical diagnostic practice molecular tools typically target well characterized and conserved portions of the genomes, particularly coding sequences, which enable accurate and reliable detection of specific pathogens including epidemiological circumstances when infection due to $R$. akari is suspected [10]. Our study augments the number of regions which can be used for identification of $R$. akari.

Previous studies demonstrated that diversity in the number of variable tandem repeats (VNTR), and occurrence and distributions of insertion and deletions (INDEL) permit reliable identification of different species and even isolates of Rickettsia [13, 14, 41, 42, 45]. Several VNTR loci were informative to distinguish geographic variants of $R$. rickettsii and confirming that $R$. rickettsii circulating in Arizona consists of unique genetic lineage $[13,14,45]$. VNTR typing targeting locus Rc-65, (in $d k s \mathrm{~A}-x e r \mathrm{C}$ intergenic region) was used for accurate and rapid differentiation between the Portuguese $R$. conorii Malish-like and Israeli tick typhus strains circulating in the same geographic locales [41], and this typing system was applied directly to ticks and clinical samples [42]. Further examination of other TR sites may find useful variable tandem repeat loci in $R$. akari. This low technology approach does not require DNA sequencing.

Intergenic spacer region analysis has permitted investigators to examine strain diversity among and within various species of Rickettsia including $R$. prowazekii, $R$. conorii, $R$. sibirica, and $R$. rickettsii $[7,16,23,47,49]$. This approach can be applied to both laboratory grown isolated strains and to field and clinical samples [7, 39] and even to fixed pathology specimens [30]. Furthermore, multispacer intergenic typing based on three regions, the $d k s \mathrm{~A}-x e r \mathrm{C}$, mppA-purC, and rpmE-tRNA ${ }^{\text {fMet }}$ spacer sequences, identified 61 genotypes among Rickettsia species, allowing the differentiation of each species by at least one distinct genotype [17]. In our study, no variations were detected within $d k s \mathrm{~A}$-xerC fragment sequenced for 14 isolates of $R$. akari; however, we detected three SNPs in two other intergenic regions, namely ligA-tgt and $t \mathrm{RNA}^{\mathrm{Leu}}-m g t$ E spacers.

Because of current views regarding the low impact and low morbidity of rickettsialpox, the specific mechanisms underlying pathogenesis of $R$. akari infection are not well examined and not fully understood beyond just a few fragmentary findings implicating the roles of macrophages and TLR 2 and TLR4 receptors in those interactions [34, 43]. In this study, we detected for the first time SNP-level diversity among geographically separated isolates of $R$. akari. One mutation we identified is responsible for a change in the amino acid sequence of a small peptide belonging to the antitoxin of a toxin-antitoxin stability system and specifically to a family of bacterial proteins which prevents the death of the host cells. Since at this point this toxin-antitoxin system is only partially characterized in rickettsiae [40], whether this mutations affects the pathogenicity of $R$. akari and the mechanisms and outcomes of their interactions with endothelial cells and macrophages is unknown. This is specifically important because recent reports of rickettsialpox from Mexico indicate unusual morbidity and severe clinical manifestations of the infection in pediatric and adult patients [46]. Our data sug- 
gests that only limited genetic diversity exists among isolates of $R$. akari associated with previous outbreaks but only a small portion of the genome has been sampled. Consequently, one useful step would be to evaluate the genome sequence of a representative strain from Ukraine and to compare its properties to the prototype US strains that have received more study. Another benefit of such analysis would be to identify additional genetic markers permitting more discriminating surveillance, tracking and studying of the vector and the host associations of these isolates.

Molecular surveys of various collections of ectoparasites besides L. sanguineus should be performed to determine the existence of mite-associated rickettsiae and their related organisms. Korean and Chinese reports have indicated that other mites may be infected with $R$. akari or $R$. akari-like organisms $[8,9,20]$. Reeves et al. also found other rickettsial agents in mites from the USA and Egypt [36, 37]. If associations of $R$. akari and its near relatives can be established with other ectoparasites, it will be impor- tant to determine if there are other wildlife reservoirs for $R$. akari or closely-related pathogens, and if disturbances in these interactions can cause rickettsialpox-like illnesses in other ecological settings.

\section{Acknowledgements}

This study was supported in part by the NIH grant AI05326-03.

This research was supported in part by an appointment of M. Sturgeon to the Emerging Infectious Diseases (EID) Fellowship Program administered by the Association of Public Health Laboratories (APHL) and funded by the Centers for Disease Control and Prevention (CDC).

The findings and conclusions in this article are those of the authors and do not necessarily represent the views of the Centers for Disease Control and Prevention.

We thank the many investigators who contributed stocks of the isolates used in this investigation.

\section{Список литературы/References}

1. Киселев Р.И., Волчанецкая Г.И. Сплошная дератизация и дезинсекция как метод борьбы с заболеваемостью оспоподобным риккетсиозом // Журнал микробиологии, эпидемиологии и иммунобиологии. 1954. № 12. С. 28 -33. [Kiselev R.I., Voltchanetskaya G.I. Complete elimination of rats and mites as the means of prevention of vesicular rickettsiosis. Zhurnal mikrobiologii, epidemiologii i immunobiologii = Journal of Microbiology, Epidemiology and Immunobiology, 1955, no. 12, pp. 28-33. (In Russ.)]

2. Киселев Р.И., Жданов В.М., Александрова Н.Н. К клинико-эпидемиологической характеристике оспоподобного риккетсиоза // Сб. тр. Харьковского НИИ вакцин и сывороток имени Мечникова. 1954. Т. ХХ. С. $253-257$. [Kiselev R.I., Zhdanov V.M., Alexandrova N.N. Clinical and epidemiological characteristics of vesicular rickettsiosis. Sbornik trudov Khar'kovskogo NII vaktsin i syvorotok imeni Mechnikova = Annals of Kharkov Mechnikov Research Institute, 1954, vol. XX, pp. 253-257. (In Russ.)]

3. Кулагин С.М. К характеристике эндемических риккетсиозов // Журнал микробиологии, эпидемиологии и иммунобиологии. 1952. Т. 12. С. 3-10. [Kulagin S.M. Characteristics of endemic rickettsiosis. Zhurnal mikrobiologii, epidemiologii i immunobiologii = Journal of Microbiology, Epidemiology and Immunobiology, 1952, no. 12, pp. 3-10. (In Russ.)]

4. Benson G. Tandem repeats finder: a program to analyze DNA sequences. Nucleic Acids Res., 1999, vol. 27, no. 2, pp. 573-580. doi: 10.1093/nar/27.2.573

5. Brouqui P., Parola P., Fournier P.E., Raoult D. Spotted fever rickettsioses in southern and eastern Europe. FEMS Immunol. Med. Microbiol., 2007, vol. 49, no. 1, pp. 2-12. doi: 10.1111/j.1574-695X.2006.00138.x

6. Brown L.D., Macaluso K.R. Rickettsia felis, an emerging flea-borne rickettsiosis. Curr. Trop. Med. Rep., 2016, vol. 3, pp. $27-39$. doi: 10.1007/s40475-016-0070-6

7. Cheng X., Jin Y., Lao S., Huang C., Huang F., Jia P., Zhang L. Multispacer typing (MST) of spotted fever group rickettsiae isolated from humans and rats in Chengmai County, Hainan Province, China. Trop. Med. Int. Health., 2014, vol. 42, no. 3, pp. 107-114. doi: 10.2149/tmh.2014-03

8. Choi Y.J., Lee E.M., Park J.M., Lee K.M., Han S.H., Kim J.K., Lee S.H., Song H.J., Choi M.S., Kim I.S., Park K.H., Jang W.J. Molecular detection of various rickettsiae in mites (Acari: Trombiculidae) in southern Jeolla Province, Korea. Microbiol. Immunol., 2007, vol. 51, no. 3, pp. 307-312. doi: 10.1111/j.1348-0421.2007.tb03912.x

9. Choi Y.J., Lee S.H., Park K.H., Koh Y.S., Lee K.H., Baik H.S., Choi M.S., Kim I.S., Jang W.J. Evaluation of PCR-based assay for diagnosis of spotted fever group rickettsiosis in human serum samples. Clin. Diagn. Lab. Immunol., 2005, vol. 12, no. 6, pp. 759-763. doi: 10.1128/CDLI.12.6.759-763.2005

10. Denison A.M., Amin B.D., Nicholson W.L., Paddock C.D. Detection of Rickettsia rickettsii, Rickettsia parkeri, and Rickettsia akari in skin biopsy specimens using a multiplex real-time polymerase chain reaction assay. Clin. Infect. Dis., 2014, vol. 59, no. 5, pp. 635-642. doi: 10.1093/cid/ciu358

11. Eremeeva M., Balayeva N., Ignatovich V., Raoult D. Genomic study of Rickettsia akari by pulsed-field gel electrophoresis. J. Clin. Microbiol., 1995, vol. 33, no. 11, pp. 3022-3024.

12. Eremeeva M.E., Balayeva N.M., Ignatovich V.F., Raoult D. Proteinic and genomic identification of spotted fever group rickettsiae isolated in the former USSR. J. Clin. Microbiol., 1993, vol. 31, no. 10, pp. 2625-2633.

13. Eremeeva M.E., Bosserman E., Zambrano M., Demma L., Dasch G.A. Molecular typing of novel Rickettsia rickettsii isolates from Arizona. Ann. NY Acad. Sci., 2006, vol. 1078, pp. 573-577. doi: 10.1196/annals. 1374.114

14. Eremeeva M.E., Dasch G.A. Closing the gaps between genotype and phenotype in Rickettsia rickettsii. Ann. NY Acad. Sci., 2009, vol. 1166, pp. 12-26. doi: 10.1111/j.1749-6632.2009.04526.x 
15. Eustis E.B., Fuller H.S. Rickettsialpox. II. Recovery of Rickettsia akari from mites Allodermanyssus sanguineus, from West Hartford, Conn. Proceedings of the Society for Experimental Biology and Medicine Society for Experimental Biology and Medicine, 1952, vol. 80, no. 3, pp. 546-549. doi: 10.3181/00379727-80-19685

16. Fournier P.E., Raoult D. Identification of rickettsial isolates at the species level using multi-spacer typing. BMC Microbiol., 2007, vol. 7, no. 7. doi: $10.1186 / 1471-2180-7-72$

17. Fournier P.E., Zhu Y., Ogata H., Raoult D. Use of highly variable intergenic spacer sequences for multispacer typing of Rickettsia conorii strains. J. Clin. Microbiol., 2004, vol. 42, no. 12, pp. 5757-5766. doi: 10.1128/JCM.42.12.5757-5766.2004

18. Frati F., Negri I., Fanciulli P.P., Pellecchia M., Dallai R. Ultrastructural and molecular identification of a new Rickettsia endosymbiont in the springtail Onychiurus sinensis (Hexapoda, Collembola). J. Invertebr. Pathol., 2006, vol. 93, no. 3, pp. $150-156$. doi: 10.1016/j.jip.2006.07.002

19. Gillespie J.J., Williams K., Shukla M., Snyder E.E., Nordberg E.K., Ceraul S.M., Dharmanolla C., Rainey D., Soneja J., Shallom J.M., Vishnubhat N.D., Wattam R., Purkayastha, A., Czar M., Crasta O., Setubal J.C., Azad A.F., Sobral B.S. Rickettsia phylogenomics: unwinding the intricacies of obligate intracellular life. PLoS One, 2008, vol. 3, no. 4: e2018. doi: 10.1371/journal. pone.0002018

20. Huang Y., Zhao L., Zhang Z., Liu M., Xue Z., Ma D., Sun X., Sun Y., Zhou C., Qin X., Zhu Y., Li W., Yu H., Yu X.J. Detection of a novel Rickettsia from Leptotrombidium scutellare mites (Acari: Trombiculidae) from Shandong of China. J. Med. Entomol., 2017, vol. 54, no. 3, pp. 544-549. doi: 10.1093/jme/tjw234

21. Huebner R.J., Peggy S., Armstrong C. 1946b. Rickettsialpox: A newly recognized rickettsial disease: I. Isolation of the etiological agent. Public Health Rep., 1946, vol. 61, no. 45, pp. 1605-1614.

22. Huebner R.J., Jellison W.L., Armstrong C. Rickettsialpox: A newly recognized rickettsial disease: V. Recovery of Rickettsia akari from a house mouse (Mus musculus). Public Health Rep., 1947, vol. 62, no. 22, pp. 777-780.

23. Karpathy S.E., Dasch G.A., Eremeeva M.E. Molecular typing of isolates of Rickettsia rickettsii by use of DNA sequencing of variable intergenic regions. J. Clin. Microbiol., 2007, vol. 45, no. 8, pp. 2545-2553. doi: 10.1128/JCM.00367-07

24. Kass E.M., Szaniawski W.K., Levy H., Leach J., Srinivasan K., Rives C. Rickettsialpox in a New York City hospital, 1980 to 1989. N. Engl. J. Med., 1994, vol. 331, no. 24, pp. 1612-1617. doi: 10.1056/NEJM199412153312403

25. Krawczak F.S., Labruna M.B., Hecht J.A., Paddock C.D., Karpathy S.E. Genotypic characterization of Rickettsia bellii reveals distinct lineages in the United States and South America. Biomed Res. Int., 2018, 8505483. doi: 10.1155/2018/8505483

26. Krinsky W.L. Does epizootic lymphocytic choriomeningitis prime the pump for epidemic rickettsialpox? Rev. Infect. Dis., 1983, vol. 5, no. 6, pp. 1118-1119. doi: 10.1093/clinids/5.6.1118

27. Kumar S., Tamura K., Nei M. MEGA3: integrated software for molecular evolutionary genetics analysis and sequence alignment. Brief. Bioinform., 2004, vol. 5, no. 2, pp. 150-163. doi: 10.1093/bib/5.2.150

28. Maina A.N., Jiang J., Luce-Fedrow A., St John H.K., Farris C.M., Richards A.L. Worldwide presence and features of flea-borne Rickettsia asembonensis. Front. Vet. Sci., 2019, vol. 5, p. 334. doi: 10.3389/fvets. 2018.00334

29. Ozturk M.K., Gunes T., Kose M., Coker C., Radulovic S. Rickettsialpox in Turkey. Emerg. Infect. Dis., 2003, vol. 9, no. 11, pp. 1498-1499. doi: 10.3201/eid0911.030224

30. Paddock C.D., Denison A.M., Lash R.R., Liu L., Bollweg B.C., Dahlgren F.S., Kanamura C.T., Angerami R.N., Pereira dos Santos F.C., Brasil Martines R., Karpathy S. Phylogeography of Rickettsia rickettsii genotypes associated with fatal Rocky Mountain spotted fever. Am. J. Trop. Med. Hyg., 2014, vol. 91, no. 3, pp. 589-597. doi: 10.4269/ajtmh.14-0146

31. Paddock C.D., Eremeeva M.E. Rickettsialpox. In: Rickettsial Diseases. Eds. Parola P., Raoult D. CRC Press, 2007, pp. 63-86.

32. Paddock C.D., Koss T., Eremeeva M.E., Dasch G.A., Zaki S.R., Sumner J.W. Isolation of Rickettsia akari from eschars of patients with rickettsialpox. Am. J. Trop. Med. Hyg., 2006, vol. 75, no. 4, pp. 732-738.

33. Paddock C.D., Zaki S.R., Koss T., Singleton J., Jr., Sumner J.W., Comer J.A., Eremeeva M.E., Dasch G.A., Cherry B., Childs J.E. Rickettsialpox in New York City: a persistent urban zoonosis. Annals of New York Academy of Sciences, 2003, vol. 990, pp. 36-44. doi: 10.1111/j.1749-6632.2003.tb07334.x

34. Quevedo-Diaz M.A., Song C., Xiong Y., Chen H., Wahl L.M., Radulovic S., Medvedev A.E. Involvement of TLR2 and TLR4 in cell responses to Rickettsia akari. J. Leukoc. Biol., 2010, vol. 88, no. 4, pp. 675-685. doi: 10.1189/jlb.1009674

35. Radulovic S., Feng H.M., Morovic M., Djelalija B., Popov V., Crocquet-Valdes P., Walker D.H. Isolation of Rickettsia akari from a patient in a region where Mediterranean spotted fever is endemic. Clin. Infect. Dis., 1996, vol. 22, no. 2, pp. $216-220$. doi: $10.1093 /$ clinids $/ 22.2 .216$

36. Reeves W.K., Dowling A.P., Dasch G.A. Rickettsial agents from parasitic dermanyssoidea (Acari: Mesostigmata). Exp. Appl. Acarol., 2006, vol. 38, no. 2-3, pp. 181-188. doi: 10.1007/s10493-006-0007-1

37. Reeves W.K., Loftis A.D., Szumlas D.E., Abbassy M.M., Helmy I.M., Hanafi H.A., Dasch G.A. Rickettsial pathogens in the tropical rat mite Ornithonyssus bacoti (Acari: Macronyssidae) from Egyptian rats (Rattus spp.). Exp. Appl. Acarol., 2007, vol. 41, no. 1-2, pp. 101-107. doi: 10.1007/s10493-006-9040-3

38. Renvoise A., van't Wout J.W., van der Schroeff J.G., Beersma M.F., Raoult D. A case of rickettsialpox in Northern Europe. Int. J. Infect. Dis., 2012, vol. 16, no. 3, pp. E221-E222. doi: 10.1016/j.ijid.2011.11.009

39. Shapiro M.R., Fritz C.L., Tait K., Paddock C.D., Nicholson W.L., Abramowicz K.F., Karpathy S.E., Dasch G.A., Sumner J.W., Adem P.V., Scott J.J., Padgett K.A., Zaki S.R., Eremeeva M.E. Rickettsia 364D: a newly recognized cause of eschar-associated illness in California. Clin. Infect. Dis., 2010, vol. 50, no. 4, pp. 541-548. doi: 10.1086/649926

40. Socolovschi C., Audoly G., Raoult D. Connection of toxin-antitoxin modules to inoculation eschar and arthropod vertical transmission in Rickettsiales. Comp. Immunol. Microbiol. Infect. Dis., 2013, vol. 36, no. 2, pp. 199-209. doi: 10.1016/j.cimid.2013.01.001.

41. Vitorino L., de Sousa R., Bacellar F., Ze-Ze L. Characterization of a tandem repeat polymorphism in Rickettsia strains. J. Med. Microbiol., 2005, vol. 54, pt. 9, pp. 833-841. doi: 10.1099/jmm.0.45956-0

42. Vitorino L., de Sousa R., Bacellar F., Ze-Ze L. Automated method based in VNTR analysis for Rickettsiae genotyping. Ann. $N Y$ Acad. Sci., 2006, vol. 1078, pp. 582-586. doi: 10.1196/annals.1374.116 
43. Walker D.H., Hudnall S.D., Szaniawski W.K., Feng H.M. Monoclonal antibody-based immunohistochemical diagnosis of rickettsialpox: the macrophage is the principal target. Mod. Pathol., 1999, vol. 12, no. 5, pp. 529-533.

44. Watson J. New building, old parasite: Mesostigmatid mites - an ever-present threat to barrier facilities. ILAR J., 2008, vol. 49, no. 3, pp. 303-309. doi: 10.1093/ilar.49.3.303

45. Wikswo M.E., Hu R., Metzger M.E., Eremeeva M.E. Detection of Rickettsia rickettsii and Bartonella henselae in Rhipicephalus sanguineus ticks from California. J. Med. Entomol., 2007, vol. 44, no. 1, pp. 158-162. doi: 10.1603/0022-2585(2007)44[158:dorrab2.0.co;2

46. Zavala-Castro J.E., Zavala-Velázquez J.E., Peniche-Lara G.F., Sulú Uicab J.E. Human Rickettsialpox, Southeastern Mexico. Emerg. Infect. Dis., 2009, vol. 15, no. 10, pp. 1665-1667. doi: 10.3201/eid1510.081507

47. Zhang L., Jin J., Fu X., Raoult D., Fournier P.E. 2006. Genetic differentiation of Chinese isolates of Rickettsia sibirica by partial ompA gene sequencing and multispacer typing. J. Clin. Microbiol., 2006, vol. 44, no. 7, pp. 2465-2467. doi: 10.1128/JCM.02272-05

48. Zhu D.T., Xia W.Q., Rao Q., Liu S.S., Ghanim M., Wang X.W. Sequencing and comparison of the Rickettsia genomes from the whitefly Bemisia tabaci Middle East Asia Minor I. Insect Science, 2016, vol. 23, no. 4, pp. 531-542. doi: 10.1111/17447917.12367

49. Zhu Y., Fournier P.E., Ogata H., Raoult D. Multispacer typing of Rickettsia prowazekii enabling epidemiological studies of epidemic typhus. J. Clin. Microbiol., 2005, vol. 43, no. 9, pp. 4708-4712. doi: 10.1128/JCM.43.9.4708-4712.2005

\section{Авторы:}

Еремеева М.Е., д.б.н., профессор, зав. лабораторией, Колледж народного здравоохранения им. Цзянн-Пин Хсу, Университет Южной Джорджии, Джорджия, Стейтсборо, США; Стуржеон М.М., магистр общественного здравоохранения, стажер, Центр контроля и профилактики заболеваний, Атланта, Джорджия, США;

Уиллард Д.к., бакалавр биологических наук, стажер, Центр контроля и профилактики заболеваний, Атланта, Джорджия, США;

Карпати С.Е., д.б.н., микробиолог, Центр контроля и профилактики заболеваний, Атланта, Джорджия, США; Мадан А., д.б.н., старший научный сотрудник, Кованс Геномик лаборатория, Редмонд, Вашингтон, США;

Даш Г.А., д.б.н., ведущий микробиолог и руководитель группы, Центр контроля и профилактики заболеваний, Атланта, Джорджия, США.

\section{Authors:}

Eremeeva M.E., PhD, MD (Biochemistry), Professor, Laboratory Director, Jiann-Ping Hsu College of Public Health, Georgia Southern University, Statesboro, GA, USA;

Sturgeon M.M., MPH, Training Fellow, Rickettsial Zoonoses Branch, Division of Vector-Borne Diseases, National Center for Emerging and Zoonotic Infectious Diseases, Centers for Disease Control and Prevention (CDC), Atlanta, Georgia, USA;

Willard J.K., BS, Training Fellow, Rickettsial Zoonoses Branch, Division of Vector-Borne Diseases, National Center for Emerging and Zoonotic Infectious Diseases, Centers for Disease Control and Prevention (CDC), Atlanta, Georgia, USA;

Karpathy S.E., PhD, Microbiologist, Rickettsial Zoonoses Branch, Division of Vector-Borne Diseases, National Center for Emerging and Zoonotic Infectious Diseases, Centers for Disease Control and Prevention (CDC), Atlanta, Georgia, USA;

Madan A., PhD, Senior Research Scientist, Covance Genomics Laboratory, Redmond, WA, USA;

Dasch G.A., PhD, Leading Microbiologist and Group Leader, Rickettsial Zoonoses Branch, Division of Vector-Borne Diseases, National Center for Emerging and Zoonotic Infectious Diseases, Centers for Disease Control and Prevention (CDC), Atlanta, Georgia, USA. 